\title{
Influence of co-culture during maturation on the developmental potential of equine oocytes fertilized by intracytoplasmic sperm injection (ICSI)
}

\author{
Xihe Li, L. H-A. Morris and W. R. Allen* \\ Thoroughbred Breeders' Association Equine Fertility Unit, Mertoun Paddocks, \\ Woodditton Road, Newmarket CB8 9BH, UK
}

The influence of co-culture with either oviduct epithelial cells or fetal fibroblast cells on in vitro maturation of equine oocytes and their potential for development to blastocysts and fetuses after intracytoplasmic sperm injection (ICSI) was investigated. The oocytes were obtained from ovaries from abattoirs and were matured in vitro for 28-30 $\mathrm{h}$ in TCM-199 only, or in TCM-199 co-culture with oviduct epithelial cells or fetal fibroblast cells. Metaphase II oocytes were subjected to ICSI with an ionomycin-treated spermatozoon. The injected oocytes were cultured for 7-9 days in Dulbecco's modified Eagle's medium. Morphologically normal early blastocysts were transferred to the uteri of recipient mares. Nuclear maturation rates and the rates of cleavage to the two-cell stage for injected oocytes were similar in the groups of oocytes that were matured in TCM-
199 (49 and 63\%), in co-culture with oviduct epithelial cells (53 and $65 \%$ ) or in co-culture with fetal fibroblasts (51 and $57 \%)$. There were no significant differences in the proportions of blastocysts that developed from the two-cell embryos derived from oocytes matured by co-culture with either oviduct epithelial cells $(30 \%)$ or fetal fibroblasts $(\mathbf{1 7} \%)$. However, significantly higher proportions of blastocysts were produced from both these co-culture groups than from the groups of oocytes matured in TCM-199 only $(P<0.05)$. Six of the blastocysts that had developed from oocytes co-cultured with oviduct epithelial cells were transferred into recipient mares and four pregnancies resulted. These results demonstrate a beneficial influence of co-culture with either oviduct epithelial cells or fetal fibroblasts for maturation of oocytes in vitro.

\section{Introduction}

Only two foals have been born using conventional methods of in vitro fertilization (IVF; Palmer et al., 1991; Bézard, 1992) and both were derived from oocytes that had been matured in vivo. Subsequently, five live foals have been reported after IVF by intracytoplasmic sperm injection (ICSI; Squires et al., 1996; Cochran et al., 1998; McKinnon et al., 2000). The first of these foals was derived from an oocyte collected from ovaries from an abattoir and matured in vitro (Squires et al., 1996), two came from oocytes recovered by follicle puncture from pregnant mares that were subsequently matured in vitro (Cochran et al., 1998) and two more originated from oocytes matured in vivo and recovered from preovulatory follicles (McKinnon et al., 2000).

During maturation within the preovulatory follicle, both the nucleus and the cytoplasm of the oocyte undergo synchronous maturation changes that ultimately result in ovulation of a metaphase II oocyte capable of undergoing normal fertilization and embryonic development (Edwards, 1965; Hunter and Polge, 1966; Leibfried-Rutledge et al., 1987). The co-ordination between these nuclear and

*Correspondence

Fax: 01638667207 cytoplasmic events has been documented in cattle by Hyttel et al. (1986) and in horses by Goudet et al. (1997). Not only must the nucleus have reached metaphase II, but it must also include the synthesis and phosphorylation of proteins involved in the resumption of meiosis, pronuclear formation and the development and activation of appropriate metabolic pathways required for further embryonic development (Hunter and Moor, 1987; Yanagimachi, 1994). Determination of the specific media required to sustain this co-ordination between nuclear and cytoplasmic maturation is somewhat limited in most species (Yanagimachi, 1994; Bavister, 1995). Furthermore, the low rate of in vitro embryo production from equine oocytes reflects the need for a better understanding of the developmental competence of equine oocytes and their specific requirements during in vitro maturation (IVM), fertilization and embryonic development. Only then will it be possible to define optimum medium and culture conditions for the production of equine embryos in vitro.

Much work has been carried out to determine the specific culture requirements to support satisfactory rates of oocyte maturation, IVF and embryonic development in many mammalian species (Yanagimachi, 1994; Bavister, 1995; Krisher and Bavister, 1998). Recently, IVF systems using semi-defined media have resulted in high rates of blastocyst production in cattle and sheep (Lu and Polge, 1992; Gardner et al., 1994) and these have now replaced 
the use of cell co-culture, or medium conditioned by cell culture, that had resulted in significant improvements in the developmental potential of in vitro-derived cattle, sheep and pig embryos a decade earlier (Gandolfi and Moor, 1987; Eyestone and First, 1989; White et al., 1989). Furthermore, in pigs, co-culture of oocytes with somatic cells during maturation improves the subsequent rates of fertilization and embryonic development in vitro (Vatzias and Hagen, 1999; Bureau et al., 2000). Therefore, similar studies are needed in horses to determine whether coculture might improve the rates of oocyte maturation, fertilization and embryo development before refinements can be made in the composition of the media.

The proportion of equine oocytes that reach the metaphase II stage of development after culture in vitro for $20-40 \mathrm{~h}$ is much lower than for other domestic species. Furthermore, only a small proportion of these metaphase II oocytes readily undergo fertilization by either IVF (Choi et al., 1994; Li et al., 1995) or ICSI (Grøndahl et al., 1997; Dell'Aquila et al., 1997a,b; Li et al., 2000). Their potential for development to the blastocyst stage is even lower, both in vitro and after transfer of zygotes or embryos at the two- to eight-cell stage into the oviducts of recipient mares (Palmer et al., 1991; Bézard, 1992; Squires et al., 1996; Cochran et al., 1998; McKinnon et al., 2000). Nevertheless, a modest proportion of in vivo-derived embryos at the one- to eight-cell stage develops to the blastocyst stage when co-cultured with a monolayer of oviduct cells (Battut et al., 1991; Ball and Miller, 1992). In addition, Carnevale et al. (2000) obtained encouraging pregnancy rates when metaphase I oocytes, obtained by oocyte aspiration $24 \mathrm{~h}$ after administration of exogenous gonadotrophins, were transferred simultaneously with spermatozoa into the oviducts of recipient mares. This important study illustrated that oocytes can complete maturation in the oviduct in vivo and be fertilized successfully thereafter. It is also worth noting that, based on the recovery of embryos from the oviducts of young and ageing mares, fertilization rates as high as $72-90 \%$ are possible (Woods et al., 1987). However, significant embryo losses must occur soon after the embryo enters the uterus on day 6 after ovulation (Battut et al., 1997), as per cycle pregnancy rates around day 15 after ovulation in well-managed Thoroughbred mares are only $62 \%$ (Morris and Allen, in press).

Thus, it is evident that many deficiencies remain in our knowledge of the conditions required to achieve satisfactory maturation of oocytes and their early development after IVF. In the present study, the benefits of co-culturing oocytes during IVM with either oviduct epithelial cells or fetal fibroblast cells were investigated, together with their potential for development in vitro and in vivo after fertilization by ICSI.

\section{Materials and Methods}

\section{Culture media}

The media used for maturation of oocytes and the development of zygotes in vitro were based on TCM-199
(22340-012; Gibco BRL, Grand Island, NY) and Dulbecco's modified Eagle's medium (22320-014; DMEM; Gibco BRL), respectively.

For maturation, TCM-199 was supplemented with $20 \%$ $(\mathrm{v} / \mathrm{v})$ heat-inactivated fetal calf serum (FCS; Gibco BRL), $10 \mu \mathrm{g} \mathrm{FSH} \mathrm{ml}^{-1}$ (Sigma Chemical Co, St Louis, MO), $5 \mu \mathrm{g}$ $\mathrm{LH} \mathrm{ml}{ }^{-1}$ (Sigma) and $1 \mu \mathrm{g}$ oestradiol $\mathrm{ml}^{-1}$ (Sigma). Culture droplets $(600 \mu \mathrm{l})$ containing 20-30 cumulus-oocyte complexes (COCs) were made under mineral oil (Sigma) in fourwell Petri culture plates (176740; Nunc, Roskilde). For development, DMEM was supplemented with $10 \%(\mathrm{v} / \mathrm{v})$ FCS, $10 \mu \mathrm{g}$ insulin $\mathrm{ml}^{-1}$ (Sigma) and $100 \mu \mathrm{mol}$ EDTA $\mathrm{l}^{-1}$ (Sigma). Likewise, $600 \mu \mathrm{l}$ culture droplets under mineral oil were used to culture groups of 20-30 zygotes in four-well Petri culture plates.

The oviduct epithelial cells used in co-culture with the oocytes during IVM were prepared by obtaining oviducts from a horse abattoir and transporting them to the laboratory at room temperature over $2 \mathrm{~h}$ in PBS containing 125 iu penicillin $\mathrm{ml}^{-1}$ and $35 \mathrm{iu}$ streptomycin $\mathrm{ml}^{-1}$. The oviducts were rinsed in fresh PBS and placed on filter paper to facilitate removal of the surrounding connective tissue. Short sections $(2-3 \mathrm{~cm}$ in length) of fresh oviduct from the ampullar region were opened with scissors and the luminal epithelial cells were scraped into a Petri dish using a scalpel blade. The resulting fragments of tissue were washed three times in TCM-199 and three or four of the fragments were added to each $600 \mu \mathrm{l}$ culture droplet of TCM-199. The mixtures were cultured for 3-4 days, during which time half the volume of medium was exchanged every other day.

The monolayer of fetal fibroblast cells used in the study originated from a horse fetus (aged 32 days) and was prepared using the method described in cattle by Dominko et al. (1999). In brief, the head and viscera of the fetus were discarded and the remaining tissues were sliced finely before enzymatic digestion in $0.5 \%(\mathrm{v} / \mathrm{v})$ trypsin-EDTA (Sigma) in PBS for $30 \mathrm{~min}$ at $30^{\circ} \mathrm{C}$. The digested fragments were washed twice in PBS by centrifugation at $700 \boldsymbol{g}$ for 10 min and the cell pellet was resuspended in DMEM supplemented with $10 \%(\mathrm{v} / \mathrm{v}) \mathrm{FCS}$ and cultured at $37^{\circ} \mathrm{C}$ in $5 \% \mathrm{CO}_{2}$ in air for 14-20 days. After the cells had been passaged twice, samples from the new growing line were frozen for future use. Subsequently, to prepare the fetal fibroblast cell monolayer for use in the oocyte maturation co-culture system, the cells were thawed and cultured in TCM-199 for 5-7 days during which time half the volume of medium was exchanged every 2 days.

Cumulus cells were harvested from COCs and grown in a monolayer in $600 \mu \mathrm{l}$ droplets of DMEM for 5-7 days, during which time half the volume of medium was exchanged every 2 days to prepare the monolayer of cumulus cells in DMEM to be used during the culture after fertilization.

\section{Oocyte collection and maturation culture}

Horse ovaries were obtained from two abattoirs and were transported to the laboratory in saline $(0.9 \%(\mathrm{w} / \mathrm{v})$ 


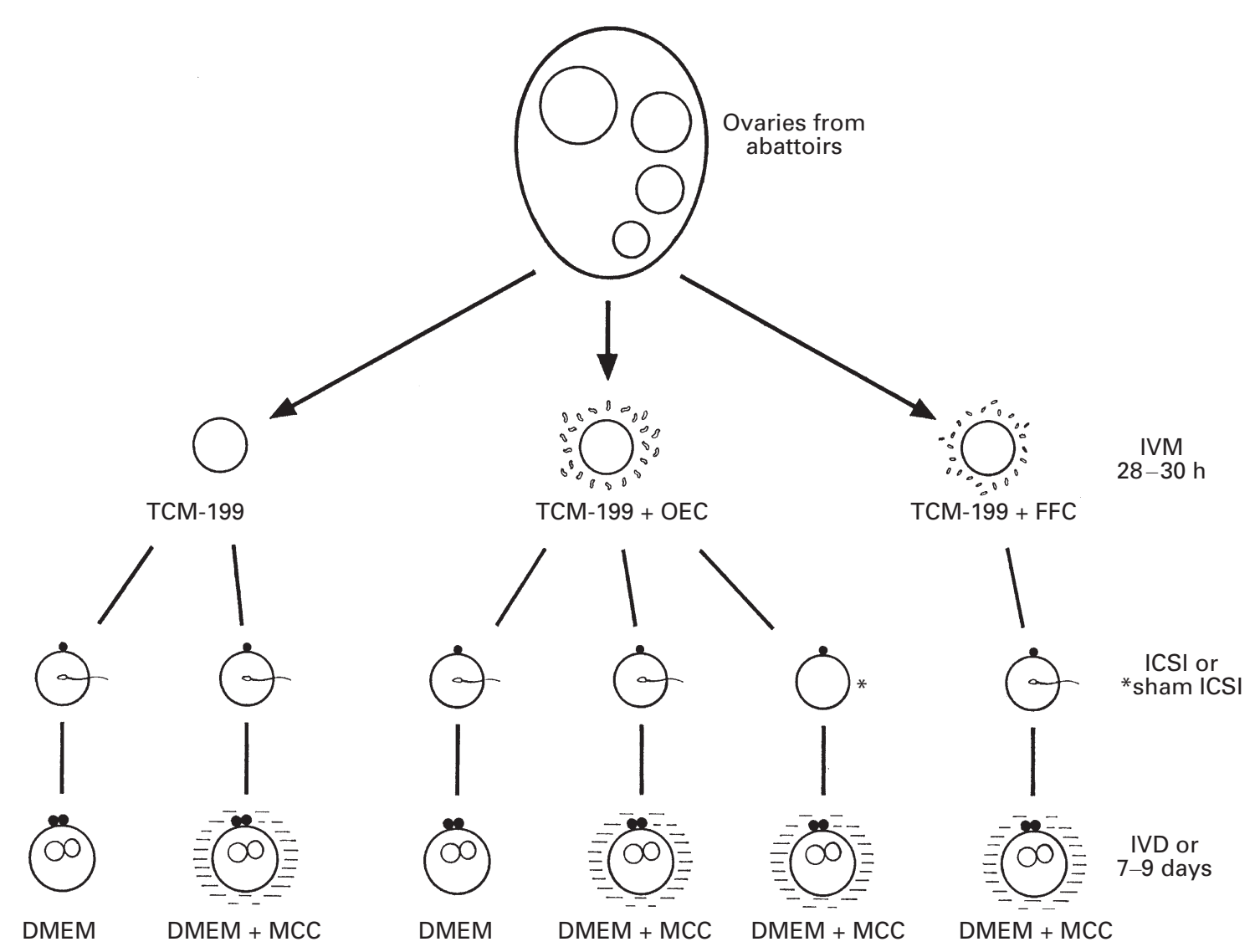

Fig. 1. Diagrammatic representation of the recovery of oocytes and in vitro maturation (IVM), fertilization by intracytoplasmic sperm injection (ICSI) and in vitro development (IVD) to produce blastocysts. OEC: oviduct epithelial cells; FFC: fetal fibroblast cells; MCC: monolayer of cumulus cells; DMEM: Dulbecco's modified Eagle's medium.

$\mathrm{NaCl})$ at room temperature $\left(12-20^{\circ} \mathrm{C}\right)$ over periods ranging from 4 to $24 \mathrm{~h}$. COCs were recovered by scraping the walls of follicles (diameter $0.5-3.0 \mathrm{~cm}$ ) and groups of 20-30 COCs were matured in vitro for $28-30 \mathrm{~h}$ at $38^{\circ} \mathrm{C}$ in $5 \% \mathrm{CO}_{2}$ in air in $600 \mu \mathrm{l}$ aliquots of TCM-199 only, or in co-culture with either oviduct epithelial cells or fetal fibroblast cells (Fig. 1).

\section{Preparation of spermatozoa for ICSI}

Ejaculated frozen-thawed spermatozoa from one of two identical twin Pony stallions of proven high fertility were used. The straws were thawed at $37^{\circ} \mathrm{C}$ for $30 \mathrm{~s}$ and the spermatozoa were then washed twice by centrifugation at $800 \mathrm{~g}$ for $10 \mathrm{~min}$ in Hepes-buffered Tyrode's medium (STALP; Grøndahl et al., 1996). The spermatozoa were resuspended in STALP containing $0.5 \mathrm{mmol} \mathrm{cAMP} \mathrm{I}^{-1}$ (Sigma) and were incubated for $4 \mathrm{~h}$ at $38^{\circ} \mathrm{C}$ and centrifuged at $400 \mathrm{~g}$ for $5 \mathrm{~min}$. The spermatozoa were transferred to STALP supplemented with $1 \mu \mathrm{mol}$ ionomycin $\mathrm{I}^{-1}$ for $10 \mathrm{~min}$ to induce capacitation (Choi et al., 2000). Finally, the concentration of spermatozoa was adjusted to $5-7 \times 10^{7}$ cells $\mathrm{ml}^{-1}$ and the suspension was maintained at $38^{\circ} \mathrm{C}$ until used for ICSI.

\section{ICSI and activation of the injected oocytes}

ICSI was performed using a Transferman Micromanipulator (Eppendorf, Hamburg) attached to an inverted microscope (IMT-2; Olympus, Tokyo). All manipulations were performed on a heated stage (CO 102; Linkam, Tadworth) that provided a working temperature of $30^{\circ} \mathrm{C}$. ICSI was carried out in $20 \mu \mathrm{I}$ droplets of $20 \mathrm{mmol}$ Hepes buffered Earle's balanced salts medium ${ }^{-1}$ (EBSS; Gibco BRL) containing 20\% (v/v) FCS and using spermatozoa that had been immobilized previously in a separate $10 \mu \mathrm{l}$ droplet of the ICSI medium that also contained 30\% (w/v) polyvinylpyrrolidone (PVP; FW 40 000; Sigma).

At the end of the 28-30 h of IVM in TCM-199 only or in TCM-199 with either oviduct epithelial cells or fetal fibroblast cells, the COCs were placed in PBS containing hyaluronidase (200 iu $\mathrm{ml}^{-1}$; Sigma) for 3-5 min before the cumulus cells were removed by gentle pipetting. Oocytes at the metaphase II stage were selected and placed into working groups of 5-10 oocytes in EBSS containing 20\% $(\mathrm{v} / \mathrm{v})$ FCS before each oocyte was injected with a spermatozoon. The injection pipette containing the spermatozoon was pushed through the zona pellucida and plasma 
membrane of the oocyte so that the spermatozoon could be injected directly into the cytoplasm. The procedure was repeated for each selected metaphase II oocyte and all the injected oocytes were then returned to the TCM-199 until the activation treatment was initiated. Sham ICSI without a spermatozoon was performed on control oocytes under the same conditions (Fig. 1).

Within 30-60 min after ICSI or sham ICSI, the injected oocytes were activated by immersion for $5 \mathrm{~min}$ in STALP containing $5 \mu \mathrm{mol}$ ionomycin $\mathrm{I}^{-1}$ (Sigma) and $1 \%(\mathrm{v} / \mathrm{v})$ ethanol. The oocytes were then washed twice in EBSS containing $20 \%$ (v/v) FCS.

\section{Development of ICSI and sham ICSI oocytes in vitro}

Groups of 20-30 injected oocytes were placed into 600 $\mu \mathrm{l}$ droplets of DMEM development culture medium, alone or in co-culture with a monolayer of cumulus cells, and were cultured for $24-30 \mathrm{~h}$ at $38^{\circ} \mathrm{C}$ in an atmosphere of $5 \%$ $\mathrm{CO}_{2}$ in air. Morphologically normal two-cell embryos were selected from all the injected oocytes that had cleaved and were cultured continuously for 6-8 days under the same conditions.

\section{Embryo transfer}

Normal cyclic mares at an equivalent stage of the oestrous cycle to the stage of embryo development were selected as recipients. Early blastocysts that appeared morphologically normal after 7 or 8 days of culture in vitro were transferred to the uteri of the recipient mares that had ovulated between 4 and 7 days previously. Pregnancy was diagnosed by ultrasonography 7-10 days after transfer and the development of the conceptus was monitored regularly thereafter by ultrasonography and measurement of serum progesterone concentrations once a week. All the recipient mares were given a daily oral dose of the synthetic progestagen altrenogest (Regumate; $0.088 \mathrm{mg} \mathrm{kg}^{-1}$; Hoechst-Intervet, Milton Keynes) from the time of embryo transfer until day 110 of gestation.

\section{Statistical analyses}

Each treatment was repeated 3-5 times and the results were evaluated by chi-squared analysis.

\section{Results}

In vitro maturation of oocytes and cleavage rates after ICSI

Similar proportions of oocytes reached the metaphase II stage of development after culture in TCM-199 only (107/ $220,49 \%)$, or in co-culture with either oviduct epithelial cells $(133 / 250,53 \%)$ or fetal fibroblast cells $(37 / 72,51 \%)$ (Table 1). Similarly, the proportions of metaphase II oocytes that cleaved after ICSI were 58 of 92 (63\%), 52 of $80(65 \%)$ and 17 of $30(57 \%)$ for each of the three maturation culture conditions, respectively, thereby revealing no apparent beneficial effect of co-culture on the rate of nuclear maturation or the early cleavage divisions. Sham ICSI resulted in cleavage of 16 of 35 oocytes (46\%) that had been matured previously in co-culture with oviduct epithelial cells.

\section{Development of two-cell embryos in vitro}

The rates of development of two-cell embryos cultured under different conditions are shown (Table 2). Only four of 16 two-cell embryos (25\%) derived from the groups of oocytes matured in TCM-199 only developed to the eightcell stage when cultured in DMEM medium alone, and none developed beyond this point. In contrast, when oocytes that had been matured without co-culture were co-cultured subsequently with a monolayer of cumulus cells after ICSI, the rate of development of the resulting two-cell embryos beyond the eight-cell stage to the 16-cell and morula stages increased significantly to ten of $20(50 \% ; P<0.05)$. Furthermore, a higher proportion of two-cell embryos that had undergone co-culture during oocyte maturation and during embryo development progressed to blastocysts (10/33, 30\%; Fig. 2), compared with two-cell embryos that had undergone co-culture during the oocyte maturation phase only and not after fertilization $(1 / 15,7 \% ; P<0.05)$.

Only two of $12(17 \%)$ two-cell embryos derived from oocytes that had been matured in co-culture with fetal fibroblast cells developed to blastocysts during 7-9 days of co-culture in DMEM with a monolayer of cumulus cells. None of the two-cell embryos obtained after sham ICSI that were co-cultured in the DMEM with a monolayer of cumulus cells progressed beyond the 16 -cell stage $(0 / 13$, Table 2), even though the original oocytes had been matured in co-culture with oviduct epithelial cells.

\section{Pregnancy and fetal development}

Six blastocysts produced from oocytes that had been matured in co-culture with oviduct epithelial cells and then co-cultured with the monolayer of cumulus cells after ICSI were of transferable quality; the other seven blastocysts showed various degrees of fragmentation that precluded them from consideration for transfer into recipient mares. The six good blastocysts were transferred to the uteri of six synchronized recipient mares, two nonsurgically via the cervix and four surgically via mid-line laparotomy as described by Allen (1982). Four mares became pregnant and the embryo transferred to the first of these developed into monozygotic twin fetuses within a single allantochorion. This pregnancy was removed from the uterus of the mare on day 76 of gestation and DNA analysis (Swinburne et al., 2000) of the two fetuses confirmed that they were monozygotic. Two mares produced healthy colt foals at days 348 and 355 of gestation, respectively, and the third mare remains pregnant.

\section{Discussion}

Conventional IVF is now used frequently in large domestic animals, such as cattle and sheep, both for research purposes 
Table 1. Nuclear maturation in equine oocytes cultured in vitro with oviductal epithelial cells or fetal fibroblast cells and their cleavage rates after intracytoplasmic sperm injection

\begin{tabular}{lcccc}
\hline Maturation medium & $\begin{array}{c}\text { Number of oocytes } \\
\text { cultured }\end{array}$ & $\begin{array}{c}\text { Number of oocytes } \\
\text { that reached } \\
\text { metaphase II (\%) }\end{array}$ & $\begin{array}{c}\text { Number of oocytes } \\
\text { subjected to ICSI }\end{array}$ & $\begin{array}{c}\text { Number that developed } \\
\text { to two-cell stage (\%) }\end{array}$ \\
\hline TCM-199 alone & 220 & $107(49)$ & 92 & $58(63)$ \\
TCM-199+ OEC & 250 & $133(53)$ & 30 & $52(65)$ \\
$16(46)$ & $17(57)$ \\
TCM-199 + FFC & 72 & $37(51)$ & 30 & $15 \%$ \\
\hline
\end{tabular}

OEC: oviductal epithelial cells; FFC: fetal fibroblast cells; ICSI: intracytoplasmic sperm injection.

*Sham ICSI was performed without injection of a spermatozoon.

There were no significant differences among groups.

Table 2. In vitro development potential of two-cell equine embryos obtained from in vitro matured oocytes fertilized by intracytoplasmic sperm injection (ICSI)

\begin{tabular}{|c|c|c|c|c|}
\hline \multirow[b]{2}{*}{ Culture medium } & \multirow{2}{*}{$\begin{array}{c}\text { Number of two-cell } \\
\text { embryos }\end{array}$} & \multicolumn{3}{|c|}{ Number (\%) of two-cell embryos that developed to } \\
\hline & & $\geqslant$ Eight-cell & $\geqslant 16$-cell or morula & Blastocyst \\
\hline \multicolumn{5}{|c|}{ Oocytes matured previously without cell co-culture } \\
\hline DMEM & 16 & $4\left(25^{\mathrm{a}}\right)$ & $0^{\mathrm{a}}$ & $0^{\mathrm{a}}$ \\
\hline $\mathrm{DMEM}+\mathrm{MCC}$ & 20 & $10\left(50^{b}\right)$ & $10\left(50^{b}\right)$ & $0^{\mathrm{a}}$ \\
\hline \multicolumn{5}{|c|}{ Oocytes matured previously with OEC co-culture } \\
\hline DMEM & 15 & $6\left(40^{\mathrm{ab}}\right)$ & $2\left(13^{\mathrm{ab}}\right)$ & $1\left(7^{a}\right)$ \\
\hline DMEM + MCC & 33 & $23\left(70^{b}\right)$ & $17\left(52^{b}\right)$ & $10\left(30^{b}\right)^{t \neq}$ \\
\hline DMEM + MCC* & 13 & $4\left(31^{a b}\right)$ & $0^{\mathrm{a}}$ & $0^{\mathrm{a}}$ \\
\hline \multicolumn{5}{|c|}{ Oocytes matured previously with FFC co-culture } \\
\hline $\mathrm{DMEM}+\mathrm{MCC}$ & 12 & $6\left(50^{\mathrm{b}}\right)$ & $5\left(42^{b}\right)$ & $2\left(17^{b}\right)^{+}$ \\
\hline
\end{tabular}

DMEM: Dulbecco's modified Eagle's medium; MCC: monolayer of cumulus cells; OEC: oviduct epithelial cell; FFC: fetal fibroblast cell.

abValues within the same column with different superscripts are significantly different $(P<0.05)$.

* Parthenogenetic embryos derived from sham ICSI.

+Some blastocysts showed fragmentation and other adverse morphological signs so were not transferred.

₹Six of these blastocysts showed good morphology and were transferred to recipient mares; four mares (67\%) became pregnant.

and for the commercial production of embryos. The importance of providing optimal culture conditions to support both nuclear and cytoplasmic maturation of primary oocytes to be used in IVF programmes has been emphasized by Bavister (1995) and Krisher and Bavister (1998). To date, between 40 and $80 \%$ of equine oocytes have reached the metaphase II stage of nuclear maturation when cultured in vitro (Fulka and Okolski, 1981; Zhang et al., 1989; Hinrichs et al., 1993; Choi et al., 1994; Li et al., 1995; Dell'Aquila et al., 1997a,b; Grøndahl et al., 1997; Hinrichs and Schmidt, 2000; Li et al., 2000), and a similar rate of maturation was achieved in the present study. However, the rate of nuclear maturation was the same whether the oocytes were matured in TCM-199 only $(107 / 220,49 \%)$ or in co-culture with oviduct epithelial cells $(133 / 250,53 \%)$ or fetal fibroblast cells $(37 / 72,51 \%)$, thereby demonstrating a lack of any beneficial effect of coculture on nuclear maturation rates in immature equine oocytes.
Simply removing oocytes from their follicles will allow resumption of meiosis (Moor and Crosby, 1986). Indeed, many immature mammalian oocytes are capable of completing meiosis in vitro, but only a small percentage of them are competent to continue development to the blastocyst stage and beyond, thereby indicating that the process of IVM may not be entirely normal (Bavister, 1995; Krisher and Bavister, 1998). In horses, only a few embryos derived from conventional IVF of oocytes matured in vitro have been transferred into recipient mares, and none of these have resulted in a pregnancy. In contrast, two pregnancies have been reported after IVF of oocytes that were matured in vivo (Palmer et al., 1991; Bézard, 1992). Consequently, it seems likely that there are differences between the developmental potential of oocytes matured in vivo versus in vitro.

In the present study, no blastocysts developed from twocell embryos obtained from oocytes that had been matured in the absence of any type of cell co-culture. However, 7 or 

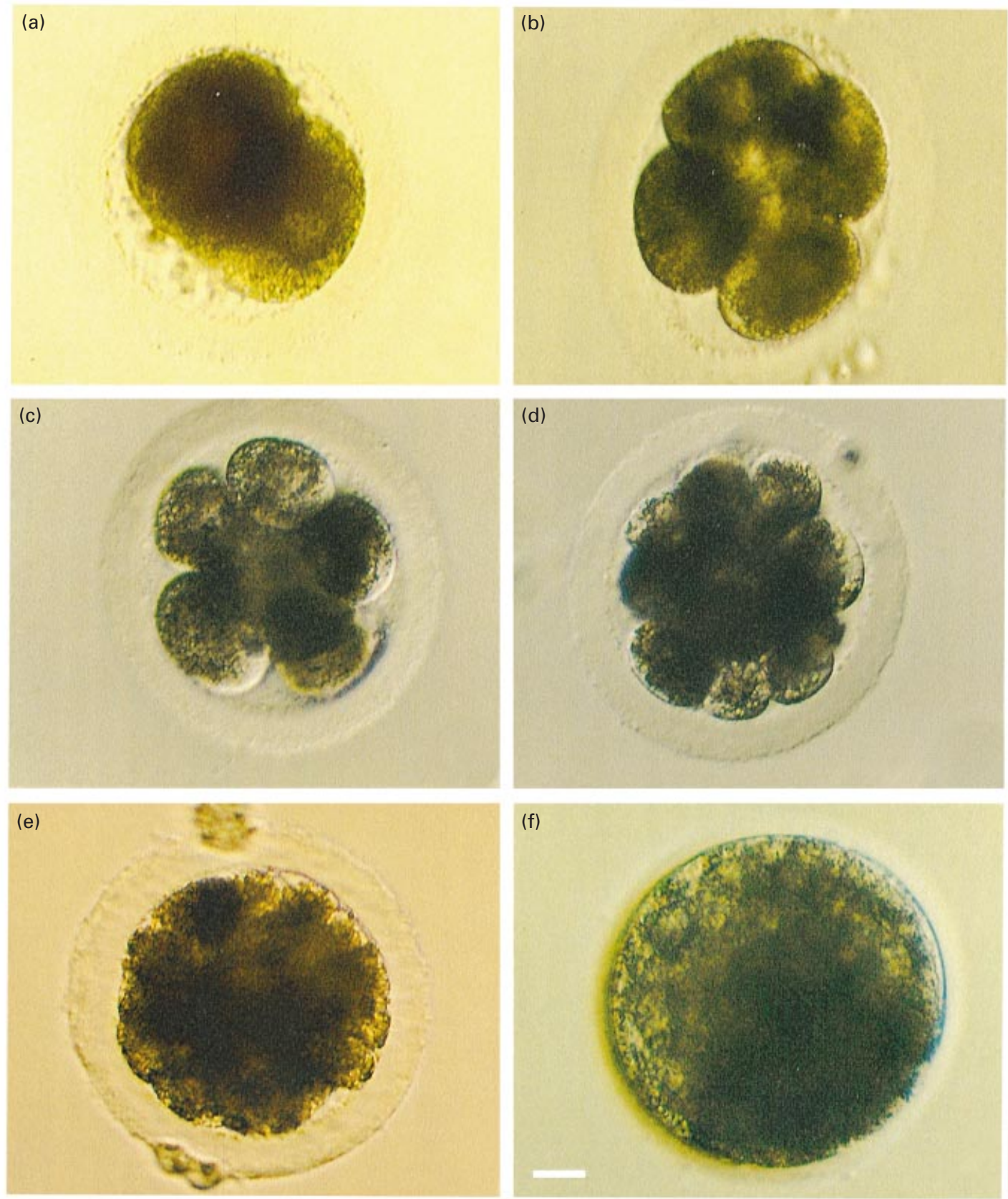

Fig. 2. In vitro development through to the blastocyst stage of a two-cell embryo derived from an in vitromatured oocyte fertilized by intracytoplasmic sperm injection (ICSI). (a) Two-cell embryo, (b) four-cell embryo, (c) eight-cell embryo, (d) 16-cell embryo, (e) morula and (f) blastocyst. Scale bar represents $20 \mu \mathrm{m}$.

$30 \%$ of two-cell embryos that had been obtained after ICSI of oocytes matured in co-culture with oviduct epithelial cells developed into blastocysts during 7-9 days of in vitro culture. Thus, it is possible that co-culture with oviduct epithelial cells during maturation enhances cytoplasmic maturation in oocytes and thereby contributes to its potential for embryo development. It could be that coculture with oviduct epithelial cells provides specific mitogenic factors that would normally be present in the oviduct, or non-specific factors that improve the culture environment such as reduction of oxygen tension, removal of waste products or provision of substrates and co-factors (Bavister, 1995).

Vatzias and Hagen (1999) and Bureau et al. (2000) have reported the value of co-culture with oviduct epithelial cells or the use of oviduct epithelial cell-conditioned medium for maturation of pig oocytes and their subsequent development to blastocysts in vitro. Beneficial effects of co-culture 
have also been observed during IVM of equine oocytes and their subsequent development as embryos (Battut et al., 1991; Ball and Miller, 1992; Dell'Aquila et al., 1997b). Indeed, Choi et al. (2000) reported blastocyst development from equine oocytes that had been fertilized by partially removing their zonae pellucidae after maturation in medium pre-conditioned with an equine trophoblast monolayer. Similarly, the results of the present study indicated that some benefits were gained from co-culturing the oocytes with fetal fibroblast cells (17\% blastocyst development) and, therefore, it appears that co-culture with either oviduct epithelial cells or fetal fibroblast cells is beneficial for maturation of equine oocytes in vitro. Furthermore, more blastocysts with less fragmentation were obtained from oocytes matured in co-culture with oviduct epithelial cells than with fetal fibroblast cells, which indicates again that oviduct epithelial cells may provide specific oviductrelated factors that enhance the developmental potential of oocytes.

Monolayers of cumulus cells have been used widely to enhance development of zygotes and early embryos from many species in vitro because they are easy to harvest and culture and have beneficial effects on embryo growth (Bavister, 1995; Krisher and Bavister, 1998). In the present study, only $7 \%$ of the two-cell embryos developed to the blastocyst stage when cultured in the absence of a monolayer of cumulus cells, whereas 30 and $17 \%$ of the two-cell embryos derived from oocytes co-cultured during maturation with oviduct epithelial cells or fetal fibroblast cells, respectively, developed into blastocysts during coculture with a monolayer of cumulus cells. These results reveal that co-culture with a monolayer of cumulus cells after fertilization also enhances the development of equine blastocysts in vitro. However, no blastocysts developed from the two-cell stage embryos produced by sham ICSI, despite maturation of the oocytes in co-culture with oviduct epithelial cells and subsequent development of the two-cell embryos in co-culture with a monolayer of cumulus cells. This finding demonstrates the developmental limitation of parthenogenetic embryos as reported in other species ( $\mathrm{Li}$ et al., 1999).

Goudet et al. (1997) observed that the ability of equine oocytes to undergo nuclear and cytoplasmic maturation in vitro is dependent on both the hormone environment within the follicular fluid and the size of the follicle from which the oocyte is obtained. Similarly, Hinrichs and Schmidt (2000) demonstrated that the meiotic competence of equine oocytes is strongly associated with the configuration of the cumulus cells surrounding them. The results of the present study indicate that, on their own, nuclear maturation and cleavage rate are not predictive of the potential of two-cell embryos to reach the blastocyst stage of development. However, the potential to develop to blastocysts is influenced by the presence or absence of cell co-culture during maturation of the oocyte. Hence, we propose that co-culture of oocytes with oviduct epithelial cells during maturation in vitro positively influences the molecular events of cytoplasmic maturation and thereby leads to improved rates of fertilization and blastocyst development. To develop and apply an in vitro method for the production of equine embryos, it is important to first develop a system that can provide blastocysts that can survive intrauterine transfer, rather than embryos still in their oviductal stages of development. In horses, only a few live offspring have been produced to date after the transfer of in vitro-derived embryos at the zygote to 16-cell stages to the oviducts of recipient mares (Palmer et al., 1991; Bézard, 1992; Squires et al., 1996; Cochran et al., 1998; McKinnon et al., 2000). In the present study, four pregnancies were established after transfer of six blastocysts produced by ICSI followed by 7-9 days of culture in vitro to the uteri of mares. The results are encouraging and demonstrate not only the beneficial influence of co-culture during oocyte maturation, but also the potential to establish an in vitro embryo production system that could be incorporated into commercial embryo transfer programmes.

The authors are grateful to R. H. F. Hunter, Edinburgh, for many helpful suggestions and his critical review of the manuscript and to M. Binns of The Animal Health Trust, Newmarket, for DNA analysis of the monozygotic twins. S. Wilsher and C. Tiplady kindly assisted with the embryo transfers. The authors would also like to thank the staff of L. J. Potter Ltd of Avon and Palmers Wholesale Butchers of Essex for supplying the horse ovaries.

\section{References}

Allen WR (1982) Embryo transfer in the horse. In Mammalian Egg Transfer pp 135-154 Ed. CE Adams. CRC Press, Boca Raton

Ball BA and Miller PG (1992) Survival of equine embryos co-cultured with equine oviductal epithelium from the four- to eight-cell to the blastocyst stage after transfer to synchronous recipient mares Theriogenology 37 979-991

Battut I, Bézard J and Palmer E (1991) Establishment of equine oviduct cell monolayers for co-culture with early equine embryos Journal of Reproduction and Fertility Supplement 44 393-403

Battut I, Colchen S, Fieni F, Tainturier D and Bruyas JF (1997) Success rates when attempting to non-surgically collect equine embryos at 144, 156 and 168 hours after ovulation Equine Veterinary Supplement 25 60-62

Bavister BD (1995) Culture of preimplantation embryos: facts and artifacts Human Reproduction Update 1 91-148

Bézard J (1992) In vitro fertilization in the mare Proceedings of the International Scientific Conference on Biotechnics in Horse Reproduction, Agricultural University of Crakow, Poland Abstract 12

Bureau M, Bailey JL and Sirard MA (2000) Influence of oviductal cells and conditioned medium on porcine gametes Zygote 8 139-144

Carnevale EM, Maclellan LJ, Scott TJ, Coutinho da Silva MA, Scoggin CF and Squires EL (2000) Effects of oocyte maturity and methods of collection, culture and insemination on equine oocyte transfer. In Proceedings of 5th International Symposium on Equine Embryo Transfer, Saari, Finland pp 34 Eds WR Allen, K Betteridge and J Wade. R\&W Publications, Newmarket

Choi YH, Okada Y, Hochi S, Braun J, Sato K and Oguri N (1994) In vitro fertilization rate of horse oocytes with partially removed zona Theriogenology 42 795-802

Choi YH, Chung YG, Seidel GE and Squires EL (2000) Culture of equine embryos in trophoblast-conditioned medium Theriogenology 53291 (Abstract)

Cochran R, Meintjes M, Reggio B, Hylan D, Carter J, Pinto C, Paccamonti D and Godke RA (1998) Live foals produced from sperm-injected 
oocytes derived from pregnant mares Journal of Equine Veterinary Science $18736-740$

Dell'Aquila ME, Cho YS, Minoia P, Traina V, Fusco S, Lacalandra GM and Maritato F (1997a) Intracytoplasmic sperm injection (ICSI) versus conventional IVF on abattoir-derived and in vitro-matured equine oocytes Theriogenology 47 1139-1156

Dell'Aquila ME, Cho YS, Minoia P, Traina V, Lacalandra GM and Maritato F (1997b) Effects of follicular fluid supplementation of in-vitro maturation medium on the fertilization and development of equine oocytes after in-vitro fertilization or intracytoplasmic sperm injection Human Reproduction 12 2766-2772

Dominko T, Mitalipova M, Haley B, Beyhan Z, Memili E, McKusick B and First NL (1999) Bovine oocyte cytoplasm supports development of embryos produced by nuclear transfer of somatic cell nuclei from various mammalian species Biology of Reproduction $601496-1502$

Edwards RG (1965) Maturation in vitro of mouse, sheep, cow, pig, rhesus monkey and human ovarian oocytes Nature 208 349-351

Eyestone WH and First NL (1989) Co-culture of early cattle embryos to the blastocyst stage with oviductal tissue or in conditioned medium Journal of Reproduction and Fertility 85 715-720

Fulka J, Jr and Okolski A (1981) Culture of horse oocytes in vitro. Journal of Reproduction and Fertility 61 213-215

Gandolfi F and Moor RM (1987) Stimulation of early embryonic development in the sheep by co-culture with oviduct epithelial cells Journal of Reproduction and Fertility 81 23-28

Gardner DK, Lane M, Spitzer A and Batt PA (1994) Enhanced rates of cleavage and development for sheep zygotes cultured to the blastocyst stage in vitro in the absence of serum and somatic cells: amino acids, vitamins and culturing embryos in groups stimulate development Biology of Reproduction 50 390-400

Goudet G, Bézard J, Duchamp G, Gerard N and Palmer E (1997) Equine oocyte competence for nuclear and cytoplasmic in vitro maturation: effects of follicle size and hormonal environment Biology of Reproduction $\mathbf{5 7}$ 232-245

Grøndahl C, Host T, Brück I, Viuff D, Bézard J, Fair T, Greve T and Hyttel P (1996) In vitro production of equine embryos Biology of Reproduction Monograph Series 1 299-307

Grøndahl C, Hansen TH, Hossaini A, Heinze I, Greve T and Hyttel P (1997) Intracytoplasmic sperm injection of in vitro-matured equine oocytes Biology of Reproduction 57 1495-1501

Hinrichs K and Schmidt AL (2000) Meiotic competence in horse oocytes: interactions among chromatin configuration, follicle size, cumulus morphology, and season Biology of Reproduction 62 1402-1408

Hinrichs K, Schmidt AL, Friedman PP, Selgrath JP and Martin MG (1993) In vitro maturation of horse oocytes: characterization of chromatin configuration using fluorescence microscopy Biology of Reproduction $48363-370$

Hunter AG and Moor RM (1987) Stage-dependent effects of inhibiting ribonucleic acids and protein synthesis on meiotic maturation of bovine oocytes in vitro. Journal of Dairy Science 70 1646-1651

Hunter RHF and Polge C (1966) Maturation of follicular oocytes in the pig after injection of human chorionic gonadotrophin Journal of Reproduction and Fertility 12 525-531

Hyttel P, Xu KP, Smith S and Greve T (1986) Ultrastructure of in vitro oocyte maturation in cattle Journal of Reproduction and Fertility 78 615-625

Krisher RL and Bavister BD (1998) Responses of oocytes and embryos to the culture environment Theriogenology 49 103-114
Leibfried-Rutledge ML, Critser ES, Eyestone WH, Northey DL and First NL (1987) Development potential of bovine oocytes matured in vitro and in vivo. Biology of Reproduction 36 376-383

Li LY, Meintjes M, Graff KJ, Paul JB, Denniston RS and Godke RA (1995) In vitro fertilization and development of in vitro-matured oocytes aspirated from pregnant mares Biology of Reproduction Monograph Series 1 309-317

Li X, Hamano K, Qian X, Funauchi K, Furudate M and Minato Y (1999) Oocyte activation and parthenogenetic development of bovine oocytes following intracytoplasmic sperm injection Zygote 7 233-237

Li X, Morris LHA and Allen WR (2000) Effects of different activation treatments on fertilization of horse oocytes by ICSI Journal of Reproduction and Fertility 119 253-260

Lu KH and Polge C (1992) A summary of two-years results in large scale in vitro bovine embryo production. In Proceedings of 12th International Congress on Animal Reproduction The Hague pp 1315-1317 Eds DJ Dieleman and B Colenbrander. Elsevier, The Hague

McKinnon AO, Lacham-Kaplan O and Trounson AO (2000) Pregnancies produced from fertile and infertile stallions by intracytoplasmic sperm injection (ICSI) of single frozen-thawed spermatozoa into in vivo matured mare oocytes Journal of Reproduction and Fertility Supplement 56 513-517

Moor RM and Crosby IM (1986) Protein requirements for germinal vesicle breakdown in ovine oocytes Journal of Embryology and Experimental Morphology 94 207-220

Morris LHA and Allen WR Reproductive efficiency in the Thoroughbred Equine Veterinary Journal (in press)

Palmer E, Bézard J, Magistrini M, Duchamp G (1991) In vitro fertilization in the horse. A retrospective study Journal of Reproduction and Fertility Supplement 44 375-384

Squires EL, Wilson JM, Kato H and Blaszczyk A (1996) A pregnancy after intracytoplasmic sperm injection into equine oocytes matured in vitro. Theriogenology 45306 (Abstract)

Swinburne J, Gerstenberg C, Breen M et al. (2000) First comprehensive low-density horse linkage map based on two, three-generation, fullsibling, cross-bred horse reference families Genomics 66 123-134

Vatzias G and Hagen DR (1999) Effects of porcine follicular fluid and oviduct-conditioned media on maturation and fertilization of porcine oocytes in vitro. Biology of Reproduction $6042-48$

White KL, Hehnke K, Rickords LF, Southern LL, Thompson DL, Jr and Wood TC (1989) Early embryonic development in vitro by coculture with oviductal epithelial cells in pigs Biology of Reproduction $\mathbf{4 1}$ 425-430

Woods GL, Baker CB, Baldwin JL, Ball BA, Bilinski J, Cooper WL, Ley WB, Mank EC and Erb HN (1987) Early pregnancy loss in brood mares Journal of Reproduction and Fertility Supplement 35 455-459

Yanagimachi R (1994) Mammalian fertilization. In The Physiology of Reproduction pp 261-268 Eds E Knobil and JD Neill. Raven Press, New York.

Zhang JJ, Boyle MS and Allen WR (1989) Recent studies on in vitro fertilization of in vitro matured horse oocytes Equine Veterinary Journal Supplement 8 101-104

Received 17 January 2001.

First decision 19 February 2001.

Accepted 2 March 2001. 